\title{
Wafer Dosing Unit
}

National Cancer Institute

\section{Source}

National Cancer Institute. Wafer Dosing Unit. NCI Thesaurus. Code C48552.

A dosing unit equal to the amount of active ing redient(s) contained in a wafer. 